\title{
On the Binding of DNA Polymerase Alpha to Nuclear Structure in Mouse Myeloma MOPC104E
}

\author{
Nobuyuki Nishioka*, Akio Matsukage** and Taijo Takahashi \\ Laboratory of Biochemistry, Aichi Cancer Center Research Institute, Nagoya \\ 464, Japan
}

\begin{abstract}
DNA polymerase $\alpha$ of mouse myeloma MOPC104E cells was resolved into at least three active types which were designated forms A, B and $\mathrm{C}$ in order of elution from DEAE cellulose column. Eighty-four percent of total DNA polymerase $\alpha$ activity of mouse myeloma MOPC104E cells was found localized in nuclei isolated using $\mathrm{Ca}^{2+}$-containing medium. Forty percent of total nuclear activity was released upon treatment with salt-free medium, and most of the remaining activity was extracted with media containing 0.15 or $0.3 \mathrm{M} \mathrm{KCl}$. The major species of $0 \mathrm{M} \mathrm{KCl}$ extract was form $\mathrm{C}$ of DNA polymerase $\alpha$, while the activity in $0.15 \mathrm{M} \mathrm{KCl}$ extract was mainly composed of form $\mathrm{B}$. The $\mathrm{KCl}$ concentration required for extraction of form $\mathrm{B}$ from the nuclei seemed to coincide with that required for the elution of DNA polymerase $\alpha$ from native DNA cellulose column. These observations suggest that form $B$ is in the complex with DNA or chromatin structure in nucleus whereas form $\mathrm{C}$ is free from the structure.
\end{abstract}

DNA polymerase alpha $(\alpha)$, one of the mammalian cellular DNA polymerases, is thought to play an important role in DNA replication from indirect observations. The level of DNA polymerase $\alpha$ activity increases in correlation with the rate of cell growth $(1,2,4,11)$ and increases during the $S$-phase of the cell cycle (16). In DNA synthesis in vitro, DNA polymerase $\alpha$ is shown capable of using RNA primers, such as (rA) $)_{12-18}$ with poly (dT) as a template or RNA chain synthesized with E. coli DNA dependent RNA polymerase with denatured DNA as a template $(17,18)$

Although DNA polymerase $\alpha$ has been observed to be localized mainly in the cytoplasm, recent finding by Lynch, Surrey and Lieberman (9) indicated that most of the DNA polymerase was associated with nuclei isolated from regenerating rat liver cells in solution containing $\mathrm{Ca}^{2+}$ and sucrose. The $7.1 \mathrm{~S}$ polymerase, thought to be DNA polymerase $\alpha$, might be easily released from nuclei in the presence of Tris- $\mathrm{HCl}$ or

*On leave from the Faculty of Pharmaceutical Sciences, Nagoya City University, Nagoya, Japan.

**To whom all correspondence should be addressed.

Abbreviations: Abbreviations for nucleotides and synthetic polynucleotides are according to the IUPAC-IUB Commission (1970). DNA polymerase, deoxynucleosidetriphosphate: DNA deoxynucleotidyltransferase, EC 2. 7. 7. 7; DNase, deoxyribonuclease; DTT, dithiothreitol; MOPC, a mineral oil plasmacytoma; KPi, potassium phosphate buffer; DEAE, diethylaminoethyl; Tris- $\mathrm{HCl}$, Tris (hydroxymethyl) aminomethane-hydrochloride buffer; EDTA, ethylenediamine tetraacetate; act. DNA, activated calf thymus DNA; BSA, bovine serum albumin. 
salts, such as $\mathrm{KCl}$ in solution in nuclear isolation. This observation suggests that DNA polymerase $\alpha$ is weakly bound with the nuclear structure.

DNA polymerase $\alpha$ from some mammalian cells is known to contain multiple forms of activity and these forms can be resolved by chromatography on DEAE cellulose $(3,5,6,10,12,14,19)$ or isoelectrofocusing (12). Studies on the active forms have indicated that their enzymological properties are similar to each other $(12,13)$, and different forms may contain common polypeptide $(s)(7,12)$. The physiological significance of the multiple forms of DNA polymerase $\alpha$ is unknown.

The present work was carried out to clarify the existence of each form in the cell. We obtained results suggesting that form B of DNA polymerase $\alpha$ is present as a complex with DNA or chromatin in the nucleus but form $\mathrm{C}$ is free from or very weakly associated with the nuclear structure.

\section{MATERIALS AND METHODS}

Materials. Mouse myeloma MOPC 104E in solid tumor was grown as previously described (10). The tumors were stored at mirus $80^{\circ} \mathrm{C}$ until used. Fresh tumors were used for subcellular fractionation experiments. Calf thymus DNA (Sigma Chemical Co.) was activated as a template/primer for MOPC 104E DNA polymerase $\alpha$ by the method described by Schlabach et al. (15). DEAE cellulose paper DE81 was purchased from Whatman Co. All other materials were previously described $(11,12)$ or were from standard commercial sources.

Enzyme assays. Two types of assays for DNA polymerase activity were employed. The reaction mixture $(25 \mu \mathrm{l})$ for assay no. 1 containing DNase I treated calf thymus DNA (activated DNA) (12) and that for assay no. 2 containing poly(rA)/(dT) $)_{12-18}(11)$ as a template/ primer were described previously except that the concentration of dTTP was $0.1 \mathrm{mM}$.

Two modifications were employed in assay no. 1. One modification was the use of Tris$\mathrm{HCl}$ at $\mathrm{pH} 7.5$ and the other modification was the use of Tris- $\mathrm{HCl}$ at $\mathrm{pH}$ 9.4. The optimal $\mathrm{pH}$ of DNA polymerase $\alpha$ is 7.5, and $\mathrm{pH} 9.4$ was employed for specific detection of DNA polymerase $\beta$ activity. At pH 9.4 DNA polymerase $\alpha$ has very little activity while DNA polymerase $\beta$ has high activity. Therefore, assays in different $\mathrm{pH}$ were used for distinguishing DNA polymerase $\alpha$ and $\beta$. After incubation usually for 60 minutes at $37^{\circ} \mathrm{C}$, the radioactive DNA product was collected on a paper disc made of DEAE cellulose (DE81) as described by Lindell et al. (8) who originally used this procedure for assay of DNA dependent RNA polymerase activity. One unit of DNA polymerase activity was defined as the amount of enzyme which catalysed the incorporation of $1 \mathrm{nmol}$ of $\left[{ }^{3} \mathrm{H}\right] \mathrm{dTMP}$ per $60 \mathrm{~min}$ into DNA.

For DNase activity measurement, the reaction mixture $(100 \mu \mathrm{l})$ was composed of the following: $50 \mathrm{mM}$ Tris- $\mathrm{HCl}$ at $\mathrm{pH} 7.8,5 \mathrm{mM} \mathrm{MgCl}_{2}, 7 \mu \mathrm{g}$ heat denatured [ ${ }^{3} \mathrm{H}$-methyl] thymine-labeled E. coli DNA (specific radioactivity of $4,000 \mathrm{cpm}$ per $\mu \mathrm{g}$ ) and $5 \mu$ laliquot of enzyme solution. After incubation at $37^{\circ} \mathrm{C}$ for $60 \mathrm{~min}$, the reaction was stopped by adding $100 \mu \mathrm{l}$ of cold $10 \%$ trichloroacetic acid and $15 \mu \mathrm{l}$ of $10 \mathrm{mg}$ per $\mathrm{ml}$ bovine serum albumin solution. The test tubes were kept for $30 \mathrm{~min}$ at $0-1{ }^{\circ} \mathrm{C}$, centrifuged for $10 \mathrm{~min}$ at 3,000 rpm, and the supernatant was collected. DNase activity was determined as radioactivity in $100 \mu$ of supernatant fraction in $10 \mathrm{ml}$ of Bray's scintillation mixture.

Subcellular fractionation. Subcellular fractionation was carried out by the method described by Lynch, Surrey and Lieberman (9). The electron micrographs of purified nuclear preparation indicated that only a very small amount of membrane fragment was contaminated in the preparation. The outer nuclear membrane still remained. The purified nuclei were used immediately after preparation for succesive extractions of DNA polymerase or were stored at minus $80^{\circ} \mathrm{C}$ until used for the standard extraction. The cytoplasmic fraction was further centrifuged at $8,500 \times \mathrm{g}$ for $12 \mathrm{~min}$ to remove mitochondria, and the supernatant 
was then centrifuged at $105,000 \times \mathrm{g}$ for $60 \mathrm{~min}$ to obtain the cytoplasmic soluble fraction (supernatant) and postmitochondrial membrane fraction (pellet). Both fractions were stored at minus $80^{\circ} \mathrm{C}$ until used for enzyme extraction.

Preparation of extract. Standard extract of DNA polymerase was made from frozen whole tumors or subcellular fractions as previously described (10). The procedure for the successive extraction of enzyme from isolated nuclei is described in the Results section.

Preparation of purified DNA polymerases $\alpha$ and $\gamma$. Partially purified DNA polymerases $\alpha$ (12) and $\gamma$ (11) were prepared by methods described previously.

Chromatographies. DEAE cellulose column chromatography was carried out by using DE32 from Whatman Co. The column was equilibrated with $30 \mathrm{mM} \mathrm{KPi} \mathrm{(pH} \mathrm{7.5)} \mathrm{containing}$ $1 \mathrm{mM}$ DTT and $20 \%$ glycerol. The extract or the partially purified DNA polymerase $\alpha$ was dialysed against the same solution as above for 12 hours at $4{ }^{\circ} \mathrm{C}$ and charged onto a column. After washing with 2 column volumes of the same buffer, the protein was eluted with a linear gradient of KPi (pH 7.5) (10 column volumes, 30 to $200 \mathrm{mM}$ in $1 \mathrm{mM}$ DTT and $20 \%$ glycerol). The eluate was collected in about 60 fractions. Protein was detected by measuring absorbance at $280 \mathrm{~nm}$. The concentration of the buffer was determined by the refractive index. Affinity chromatography of DNA polymerase $\alpha$ or $\gamma$ on DNA cellulose column was carried out by procedures previously described $(11,12)$.

\section{RESULTS}

Resolution of multiple forms of DNA polymerase $\alpha$ in crude extract with DEAE cellulose column chromatography. In a previous paper (12), we reported that partially purified DNA polymerase $\alpha$ was resolved into at least three active forms with DEAE cellulose column chromatography. The first activity, designated form A, was eluted from the column with about $70 \mathrm{mM} \mathrm{KPi}$ at $\mathrm{pH} 7.5$, and form $\mathrm{B}$ and form $\mathrm{C}$ were eluted with 100 and $150 \mathrm{mM} \mathrm{KPi}$, respectively.

The crude extract prepared from whole MOPC104E tissue by the procedure described previously (10) was fractionated with $25-65 \%$ saturated ammonium sulfate and then chromatographed on a DEAE cellulose column. As shown in Fig. 1, three prominent peaks of DNA polymerase activity were detected under assay no. 1. The $\mathrm{KPi}$ concentrations at the three DNA polymerase activity peaks were 70, 100 and 150 $\mathrm{mM}$, and they coincided closely with the KPi concentrations for elutions of purified forms A, B and C (12). From these findings and their enzymological properties (data not shown), these activities are thought to be identical to the three active forms of DNA polymerase $\alpha$. In addition, a small peak of DNA polymerase activity detected under assay no. 1 and 2 was observed in the flow-through fraction. The DNA polymerase in this fraction had higher activity at $\mathrm{pH} 9.4$ than at $\mathrm{pH} 7.5$. Therefore, it is thought to be DNA polymerase $\beta$. At about $50 \mathrm{mM} \mathrm{KPi}$, the activity detected under assay no. 2 might be DNA polymerase $\gamma$. DNase activity was detected only in the flow-through fraction (data not shown).

The chromatographic procedure employed here made it possible to identify the active forms of DNA polymerase $\alpha$ in the crude extract and determine their quantities.

Localization of DNA polymerase $\alpha$. DNA polymerase $\alpha$ has been observed to be localized mainly in the cytoplasm. However Lynch, Surrey and Lieberman (9) have systematically examined the conditions for nuclear isolation and found that most 7.1 S DNA polymerase, thought to be DNA polymerase $\alpha$, was localized in nuclei isolated from regenerating rat liver in the presence of $4 \mathrm{mM} \mathrm{Ca}^{2+}$ and $0.3 \mathrm{M}$ sucrose. 


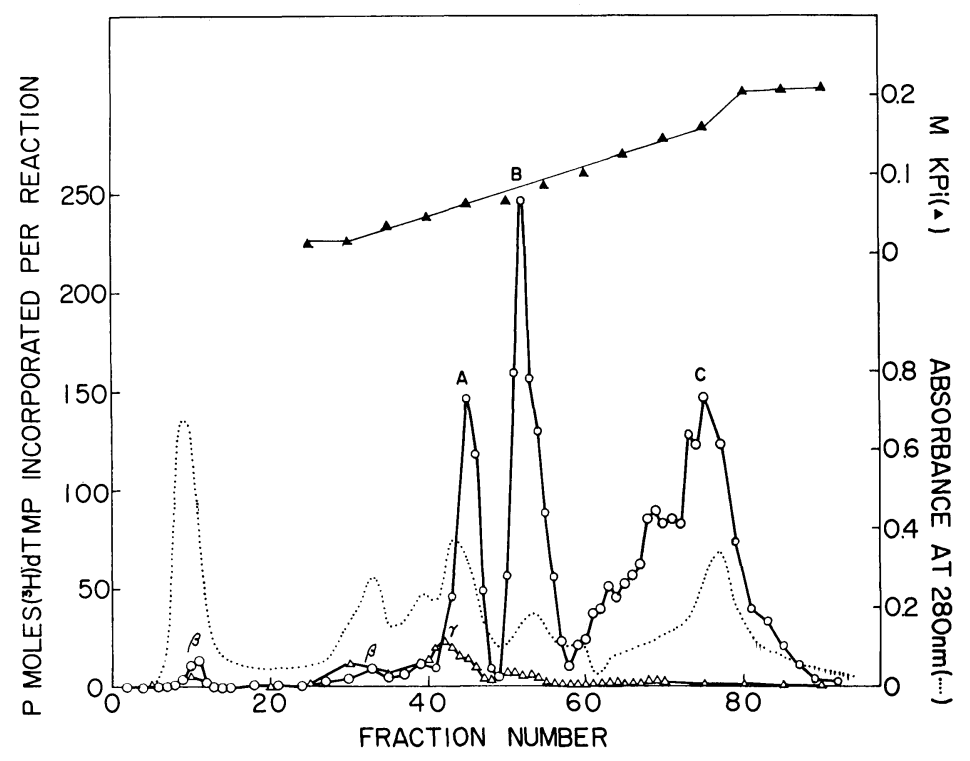

Fig. 1. DEAE-cellulose column chromatography of the extract of mouse myeloma MOPC-104E. The crude extract of MOPC-104E prepared as described under Materials and Methods was fractionated with $25-65 \%$ saturated $\left(\mathrm{NH}_{4}\right)_{2} \mathrm{So}_{4}$, and dialyzed against $30 \mathrm{mM} \mathrm{KPi}$ at pH 7.5 containing $1 \mathrm{mM}$ DTT and $20 \%(\mathrm{v} / \mathrm{v})$ glycerol for 7 hours at $4^{\circ} \mathrm{C}$. The extract was applied onto a DEAEcellulose column equilibrated with the same solution, and the column was washed with 2 column volumes of the same solution. The protein was eluted with a linear KPi gradient of 7 column volumes from 30 to $250 \mathrm{mM}$ in $1 \mathrm{mM}$ DTT, $20 \%$ glycerol. The size of column was $1.6 \times 30 \mathrm{~cm}$, and the volume of gradient was $400 \mathrm{ml}$. The solution flow rate was $25 \mathrm{ml}$ per hour, and each fraction contained $5 \mathrm{ml}$ of eluate. Protein was detected by measuring the absorbance at $280 \mathrm{~nm}$, and the KPi concentration was determined by the refractive index. DNA polymerase activity under assay no. $1(\circ)$ or assay no. $2(\triangle)$ was measured using a $3 \mu \mathrm{l}$ aliquot of each fraction. Reaction was carried out for $60 \mathrm{~min}$ at $37^{\circ} \mathrm{C}$. $\mathrm{A}, \mathrm{B}$ and $\mathrm{C}$ in the figure indicate forms $\mathrm{A}, \mathrm{B}$ and $\mathrm{C}$ of DNA polymerase $\alpha$, respectively, and $\beta$ and $\gamma$ indicate DNA polymerases $\beta$ and $\gamma$, respectively.

We employed this method for subcellular fractionation of MOPC104E cells. The enzyme was extracted from nuclear, postmitochondrial membrane fraction or soluble fraction as well as from whole tissue under the standard extraction condition described in the methodology section, and the enzyme was analysed by DEAE cellulose column chromatography. The activity in each subcellular fraction is shown in Table 1. Eightyfour percent of total activity was found to be localized in nuclei which differs from results obtained with nuclei isolated by the ordinary method using solution containing Tris- $\mathrm{HCl}$ and $\mathrm{MgCl}_{2}$ (12).

The results also indicate that total DNA polymerase activity extracted from subcellular fractions (394 units per gram tissue) accounts for activity extracted from whole tissue ( 387 units per gram tissue). This finding rules out the possibility that the selective inactivation of cytoplasmic DNA polymerase $\alpha$ during subcellular fractionation process resulted in the low cytoplasmic DNA polymerase level.

Stepwise extraction of DNA polymerase activity from purified nuclei. DNA polymerase was extracted from purified nuclei with solution containing $10 \mathrm{mM}$ Tris- $\mathrm{HCl}$ 
TABLE 1. Distribution OF DNA POLYMERASE $\alpha$ ACTIVITY IN SUBCELlULAR FRACTIONS UNDER DIFFERENT CONDITIONS OF FRACTIONATION

\begin{tabular}{lrrr}
\hline & \multicolumn{2}{c}{ Amount of DNA polymerase $\alpha$} \\
\cline { 2 - 4 } Subcellular fraction & Condition no. $1^{a}$ & \multicolumn{2}{c}{ Condition no. $2^{b}$} \\
\hline Nuclear & $\%$ & $\%$ & Units/g of tissue \\
Cytoplasmic & 12 & 84 & 330 \\
$\quad$ Postmitochondrial membrane & 88 & 16 & 63.6 \\
$\quad$ Soluble & 9 & 2 & 6.6 \\
Unfractionated & 79 & 14 & 57.0 \\
\hline
\end{tabular}

a Solution for subcellular fractionation contained $10 \mathrm{mM}$ Tris- $\mathrm{HCl}(\mathrm{pH} 7.5), 4 \mathrm{mM} \mathrm{Mg}$ acetate, $1 \mathrm{mM}$ DTT and $0.25 \mathrm{M}$ sucrose (12).

$b$ Solution for subcellular fractionation contained $44 \mathrm{mM} \mathrm{CaCl}_{2}$ and $0.3 \mathrm{M}$ sucrose (9).

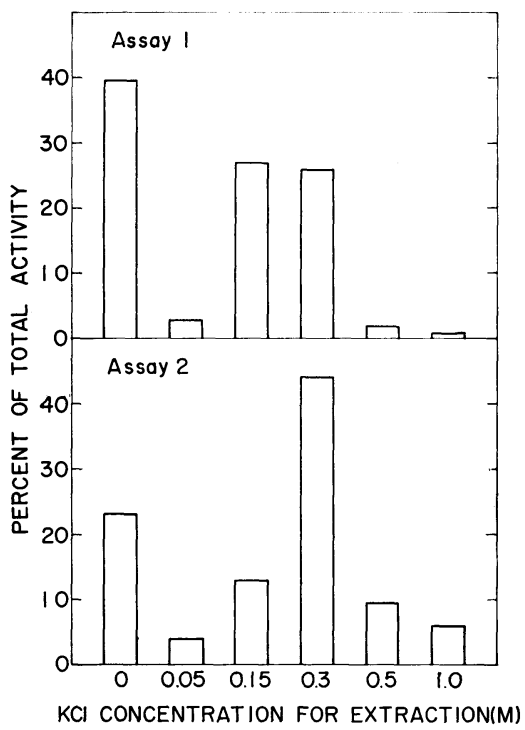

Fig. 2. Stepwise extraction of DNA polymerase from purified nuclei of mouse myeloma. Nuclei were isolated from $19.8 \mathrm{~g}$ of fresh MOPC-104E by the method of Lynch, Surrey and Lieberman (9), and suspended in the $10 \mathrm{ml}$ of extraction buffer $(10 \mathrm{mM}$ Tris- $\mathrm{HCl} \mathrm{pH} 7.3,1 \mathrm{mM}$ DTT, $0.1 \mathrm{mM}$ EDTA) containing no $\mathrm{KCl}$ and stirred for $30 \mathrm{~min}$ at $0-1^{\circ} \mathrm{C}$. The extract was separated from the precipitate by centrifugation for $10 \mathrm{~min}$ at $3,000 \mathrm{rpm}$ and the precipitate was then extracted by the extraction buffer containing $0.05 \mathrm{M} \mathrm{KCl}$ by the same procedure described previously. This procedure was repeated using stepwise increases in $\mathrm{KCl}$ concentration. A $2 \mu \mathrm{l}$ aliquot of each extract was used for determination of DNA polymerase activity in assay no. 1 and assay no. 2.

at $\mathrm{pH} 7.3,0.1 \mathrm{mM}$ EDTA, $1 \mathrm{mM}$ DTT and $\mathrm{KCl}$. Nuclei were initially suspended in solution containing no $\mathrm{KCl}$ using a very loosely fitting homogenizer with a rubber pestle, and the suspension was stirred gently for $30 \mathrm{~min}$ at $0-1^{\circ} \mathrm{C}$. The pellet obtained by centrifugation for $10 \mathrm{~min}$ at $2,150 \times \mathrm{g}$ was again extracted with solution containing $0.05 \mathrm{M} \mathrm{KCl}$ by the same procedure. Thus, extracts were prepared using the solution containing $0,0.05,0.15,0.30,0.50$ and $1.0 \mathrm{M} \mathrm{KCl}$. The DNA polymerase activity of each extract was measured under assays no. 1 and 2 (Fig. 2). Thirty-nine percent of 


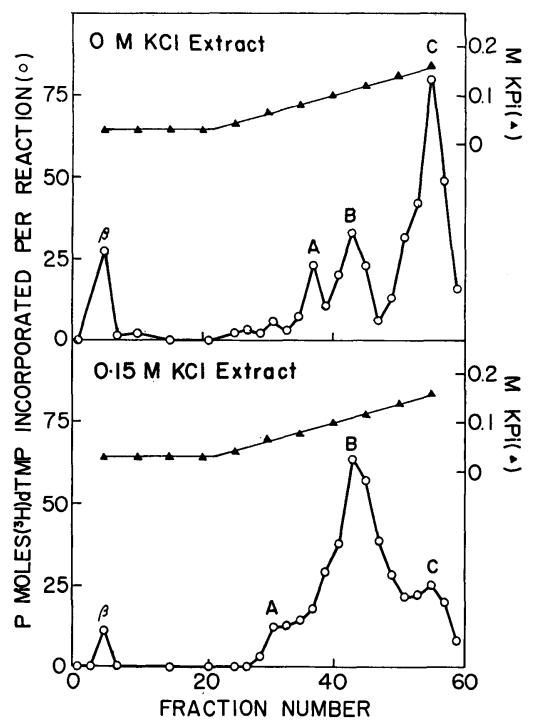

Fig. 3. DEAE-cellulose column chromatography of DNA polymerase extracted from nuclei with $0 \mathrm{M}$ or $0.15 \mathrm{M} \mathrm{KCl}$. The protein in the extract was prepared as described in the legend of Fig. 2 using the extraction solution containing $0 \mathrm{M}$ or $0.15 \mathrm{M} \mathrm{KCl}$, precipitated with $75 \%$ saturated $\left(\mathrm{NH}_{4}\right)_{2} \mathrm{SO}_{4}$ and redissolved in $30 \mathrm{mM} \mathrm{KPi}$ at pH 7.5 containing $1 \mathrm{mM}$ DTT and $20 \%$ glycerol. After dialysis against 100 volumes of the same solution, the protein was applied onto a DEAE-cellulose column. The column was washed with 2 column volumes of solution containing $30 \mathrm{mM} \mathrm{KPi}$. Protein was eluted with 7 volumes of linear KPi gradient at $\mathrm{pH} 7.5$ in $1 \mathrm{mM}$ DTT and $20 \%$ glycerol. The sample containing about $4 \mathrm{mg}$ protein was charged onto a $0.7 \times 18 \mathrm{~cm}$ column. The flow rate was $3 \mathrm{ml}$ per hour and 1 fraction contained $1 \mathrm{ml}$ of eluate. DNA polymerase activity in a $5 \mu 1$ aliquot of each fraction was determined by assay no. 1 . KPi concentration was determined by measuring the refractive index.

activity detected under assay no. 1 was extracted with solution containing no $\mathrm{KCl}$ while most of the remaining activity was extracted after changing the $\mathrm{KCl}$ concentration to 0.15 or $0.3 \mathrm{M}$. Only a very small amount of activity was extracted with solution containing $0.05 \mathrm{M} \mathrm{KCl}$ or with $\mathrm{KCl}$ higher than $0.3 \mathrm{M}$. These results indicate the presence of at least two types of DNA polymerase activities with different binding strength to nuclear structure. On the other hand, most activity detected under assay no. 2 was extracted with $0.3 \mathrm{M} \mathrm{KCl}$, and this activity was thought composed of DNA polymerase (s) $\beta$ and/or $\gamma$.

DNA polymerase activities extracted with $0 \mathrm{M}$ and $0.15 \mathrm{M} \mathrm{KCl}$ were analysed separately with DEAE cellulose column chromatography. As seen in Fig. 3, the major activity in the $0 \mathrm{M} \mathrm{KCl}$ extract was form $\mathrm{C}$ of DNA polymerase $\alpha$ while that in $0.15 \mathrm{M} \mathrm{KCl}$ extract was form $\mathrm{B}$. A preliminary experiment indicated that the main activity in $0.3 \mathrm{M} \mathrm{KCl}$ extract was also form $\mathrm{B}$.

Affinity chromatography of forms $B$ and $C$ of DNA polymerase $\alpha$ and DNA polymerase $r$ on DNA cellulose column. Forms B and C of DNA polymerase $\alpha$ were purified to the second step of DEAE cellulose chromatography as previously described (12). The DNA affinity of each activity was examined using native calf thymus DNA 
cellulose column. Each form was dialysed against $10 \mathrm{mM}$ Tris- $\mathrm{HCl}$ at $\mathrm{pH} \mathrm{7.5,} \mathrm{con-}$ taining $10 \mathrm{mM} \mathrm{KCl}, 1 \mathrm{mM}$ DTT, $0.1 \mathrm{mM}$ EDTA and $20 \%$ glycerol for $4 \mathrm{~h}$ at $0-1{ }^{\circ} \mathrm{C}$, and charged onto a column. Then the column was washed with solution changed stepwise in $\mathrm{KCl}$ concentrations $(0.06,0.20$ and $1.0 \mathrm{M})$. As seen in Fig. 4, most form $\mathrm{B}$ activity was eluted after changing the $\mathrm{KCl}$ concentration to $0.20 \mathrm{M}$, while $60 \%$ of form $\mathrm{C}$ activity was eluted after changing the $\mathrm{KCl}$ concentration to $0.06 \mathrm{M}$ and the remainder was eluted with $0.2 \mathrm{M} \mathrm{KCl}$. This result indicates that form $\mathrm{C}$ had a somewhat lower affinity to DNA cellulose than form B.

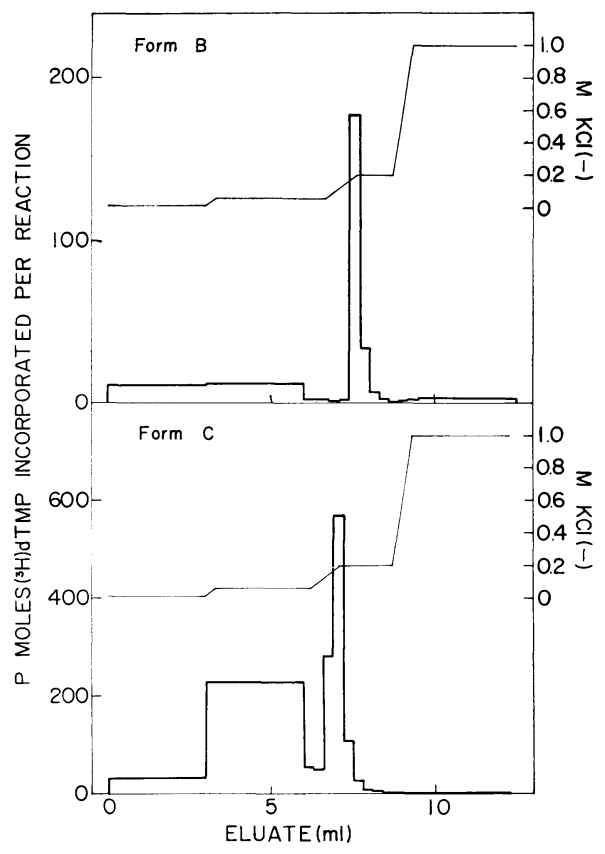

Fig. 4. Affinity chromatography of forms B and C of DNA polymerase $\alpha$ on native calf thymus DNA-cellulose. Each form was prepared to the second DEAE cellulose step as described previously (12). After dialysis against $10 \mathrm{mM}$ Tris- $\mathrm{HCl}$ at $\mathrm{pH} 7.5$ containing $10 \mathrm{mM} \mathrm{KCl}, 1 \mathrm{mM} \mathrm{DTT}, 0.1 \mathrm{mM}$ EDTA and $20 \%$ glycerol, the enzyme was charged onto a $0.5 \times 5 \mathrm{~cm}$ DNA cellulose column and eluted with stepwise changes in $\mathrm{KCl}$ concentration to $0.06,0.2$ and $1.0 \mathrm{M}$ in $10 \mathrm{mM}$ Tris- $\mathrm{HCl}, 1 \mathrm{mM}$ DTT, $0.1 \mathrm{mM}$ EDTA and $20 \%$ glycerol. DNA polymerase activity in a $2 \mu 1$ aliquot of each fraction was determined under the assay no. 1 condition. The recovery activity of form $\mathrm{B}$ and $\mathrm{C}$ was about $150 \%$.

It should be pointed out that the $\mathrm{KCl}$ concentration required for elution of form $\mathrm{B}$ from DNA cellulose column was similar to the $\mathrm{KCl}$ concentration $(0.05-0.15 \mathrm{M})$ used for the extraction of DNA polymerase $\alpha$ form B from the purified nuclei.

Fig. 5 shows that DNA polymerase $r$ was eluted from DNA cellulose with solution containing $0.25 \mathrm{M} \mathrm{KCl}$, and this observation also coincides with the evidence that the major portion of DNA polymerase detected with poly $(\mathrm{rA}) /(\mathrm{dT})_{12-18}$ as a template/ 


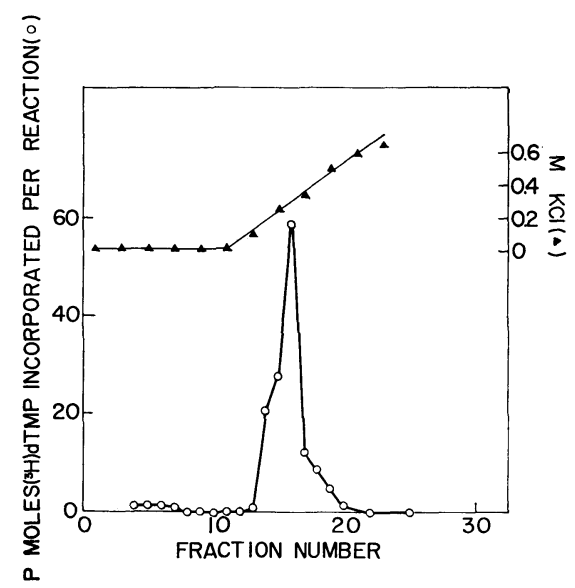

Fig. 5. Affinity chromatography of DNA polymerase $r$ on native calf thymus DNA cellulose. DNA polymerase $\gamma$ purified after hydroxyapatite column' chromatography (11) was chromatographed on a native DNA-cellulose column as described in the Fig. 4 legend, except for the use of a linear $\mathrm{KCl}$ gradient for elution instead of stepwise changes. The DNA polymerase activity of a $2 \mu 1$ aliquot of each fraction was measured under assay no. 2 . Incubation time was $30 \mathrm{~min}$ at $37^{\circ} \mathrm{C}$.

primer was extracted from nuclei at $\mathrm{KCl}$ concentrations between 0.15 and $0.3 \mathrm{M}$ (Fig. 2).

\section{DISCUSSION}

There are several reports indicating that DNA polymerase $\alpha$ is composed of multiple forms of activity $(3,5,6,10,12,14,19)$. This heterogeneity is thought to be native rather than an artifact of the extraction or fractionation procedure, because multiple forms of DNA polymerase $\alpha$ were observed in crude extracts prepared from nuclei or whole cells under very mild conditions or in the presence of protease inhibitors (12). Furthermore, conversions from one form to another during fractionation were not observed (12).

In our results $(12,13)$, the three forms designated as A, B and C in order of elution from DEAE cellulose were very similar in enzymological properties in spite of minor difference. Recent studies on the structure of DNA polymerase $\alpha$ suggest that these forms share the common polypeptide (7). Forms $\mathrm{A}$ and $\mathrm{C}$ sediment at 6-7 S while form B sediments at 8-9 S in glycerol gradient (data not shown). These observations suggest that form B may be composed of common polypeptide(s) as A or C and additional polypeptide(s) of rather low molecular weight. Observations supporting this possibility were reported by Holmes, Hesslewood and Johnston (7).

The results described in this communication indicate that form $\mathrm{B}$ might bind to some structure in the nucleus. This structure in the nucleus is presumably DNA or chromatin, because the $\mathrm{KCl}$ concentration required for extraction of DNA polymerase $\alpha$ form B from nuclei seems to coincide with the $\mathrm{KCl}$ concentration for elution of this activity from the DNA cellulose column. On the other hand, form $\mathrm{C}$ is present in fraction extracted with solution containing no $\mathrm{KCl}$ and is shown to have less binding 
ability to DNA cellulose. This suggests that form $\mathrm{C}$ is free from or very weakly bound to the nuclear structure. Therefore, it may be possible to propose a hypothesis that form B is an active form of DNA polymerase $\alpha$ in the DNA replication system. The minor polypeptide(s), which accounts for the difference between the sedimentation values of forms $\mathrm{B}$ and $\mathrm{C}$ may be the accessory protein(s) required for the binding of DNA polymerase to DNA or chromatin and also for activation of the enzyme in DNA replication.

Our preliminary data not shown here indicate that most DNA polymerase $\alpha$ in the cytoplasmic soluble fraction is in form C. Several possibilities on the significance of form $\mathrm{C}$ can be considered. (a) Form $\mathrm{C}$ is released from the DNA replication complex in which form B is an active form, and can be converted again into form B by binding with the accessory polypeptide(s). (b) Form $\mathrm{C}$ is the intermediate during the degradation process of DNA polymerase $\alpha$. (c) Form $\mathrm{C}$ is the form just after new synthesis of DNA polymerase $\alpha$.

We did not obtain clear results on form A, as the quantity collected was too small for analysis by our procedure.

Acknowledgments. We wish to thank Dr. I. Suzuki, Laboratory of Ultrastructure Research of this institute, for electron microscopic work, Mr. R. Ishida for the gift of $\left[{ }^{3} \mathrm{H}\right]$-labeled E. coli DNA, Dr. K. Tanabe for his discussion and Miss M. Nishizawa and Miss I. Inagaki for their expert technical assistance.

\section{REFERENCES}

1. Baril, E.F., M.D. Jenkins, O.E. Brown, J. LASzlo and H.P. Morris. DNA polymerases I and II in regenerating rat liver and Morris hepatoma. Cancer Res. 33, 1187-1193, 1973

2. Chang, L.M.S. and F.J. Bollum. Variation of deoxyribonucleic acid polymerase activities during rat liver regeneration. J. Biol. Chem. 247, 7948-7950, 1972

3. Craig, R.K. and H.M. KeIR. Deoxyribonucleic acid polymerases of BHK-21/c13 cells: Heterogeneity, molecular asymmetry and subcellular distribution of the enzymes. Biochem. J. 145, 225-232, 1975

4. DAVIS, P.B., J. LASZlo and E.F. BARIL. Induction of DNA polymerase $\alpha$ during liver regeneration in rats on controlled feeding schedules. Cancer Res. 36, 432-437, 1976

5. Hachmann, H.J. and A.G. Lezins. High molecular-weight DNA polymerases from mouse myeloma: Purification and properties of three enzymes. Eur. J. Biochem. 50, 357-366, 1975

6. Holmes, A.M., I.P. Hesslewood and I.R. Johnston. The occurrence of multiple activities in the high-molecular-weight DNA polymerase fraction of mammalian tissues: A preliminary study of some of their properties. Eur. J. Biochem. 43, 487-499, 1974

7. Holmes, A.M., I.P. Hesslewood and I.R. Johnston. Evidence that DNA polymerases- $\alpha$ of calf thymus contains a subunit of molecular weight 155,000. Eur. J. Biochem. 62, 229-235, 1976

8. Lindell, T.J., F. Weinberg, P.W. Morris, R.G. Roeder and W.J. RutTer. Specific inhibition of nuclear RNA polymerase II by $\alpha$-amanitin. Science 170, 447-449, 1970

9. LYNCH, W.E., S. SURREY and I. Lieberman. Nuclear deoxyribonucleic acid polymerase of liver. J. Biol. Chem. 250, 8179-8183, 1975

10. Matsukage, A., E.W. Bohn and S.H. Wilson. Multiple forms of DNA polymerase in mouse myeloma. Proc. Natl. Acad. Sci. USA 71, 578-582, 1974

11. Matsukage, A., E.W. Bohn and S.H. Wilson. On the DNA polymerase III of mouse myeloma: Partial purification and characterization. Biochemistry 14, 1006-1020, 1975

12. Matsukage, A., M. Sivarajan, and S.H. Wilson. Studies on DNA $\alpha$-polymerase of mouse myeloma: Partial purification and comparison of three molecular forms of the enzyme. Biochemistry 15, 5305-5314, 1976

13. Matsukage, A., Manuscript in preparation 
14. Momparler, R.L., M. Rossi and A. Labitan. Partial purification and properties of two forms of deoxyribonucleic acid polymerase from calf thymus. J. Biol. Chem. 248, 285-293, 1973

15. Schlabach, A., B. Fridlender, A. Bolden and A. Weissbach. DNA-dependent DNA polymerases from HeLa cell nuclei. II. Template and substrate utilization. Biochem. Biophys. Res. Commun. 44, 879-885, 1971

16. Spadari, S. and A. Weissbach. The interrelation between DNA synthesis and various DNA polymerase activities in synchronized HeLa cells. J. Mol. Biol. 86, 11-20, 1974

17. Spadari, S. and A. Weissbach. RNA-primed DNA synthesis: Specific catalysis by HeLa cell DNA polymerase $\alpha$. Proc. Natl. Acad. Sci. USA 72, 503-507, 1975

18. Wilson, S.H., A. Matsukage and E.W. Bohn. Specificity of alpha class DNA polymerase from mouse myeloma: A systematic survey of the template-primer preference and the mechainsm of action. Submitted for publication.

19. Yoshida, S., T. Kondo and T. ANDo. Multiple molecular species of cytoplasmic DNA polymerase from calf thymus. Biochim. Biophys. Acta 353, 463-474, 1974

(Received for publication, January 5, 1977) 